MOL 7054

The Hypolipidemic Natural Product Guggulsterone is a Promiscuous Steroid

\title{
Receptor Ligand
}

Thomas P. Burris ${ }^{1,2}$, Chahrzad Montrose ${ }^{1}$, Keith A. Houck ${ }^{1}$, Harold E. Osborne ${ }^{1}$, Wayne P. Bocchinfuso ${ }^{1}$, Benjamin C. Yaden ${ }^{1}$, Christine C. Cheng ${ }^{1}$, Richard W. Zink ${ }^{1}$, Robert J. Barr $^{1}$, Christoper D. Hepler ${ }^{1}$, Venkatesh Krishnan ${ }^{1}$, Heather A. Bullock ${ }^{1}$, Lorri L. Burris ${ }^{1}$, Rachelle J. Galvin ${ }^{1}$, Kelli Bramlett ${ }^{1,2}$, Keith R. Stayrook ${ }^{1}$

${ }^{1}$ Lilly Research Laboratories, Lilly Corporate Center, Indianapolis, IN 46285

${ }^{2}$ Department of Pharmacology and Toxicology, Indiana University School of Medicine, Indianapolis, IN 46202 
MOL 7054

Running Title: Guggulsterone is a promiscuous steroid receptor ligand

Corresponding Author: Dr. Thomas P. Burris, Lilly Research Laboratories, Lilly

Corporate Center, Indianapolis, IN 46285, 317-433-4962, fax 317-276-1414,

burris@ lilly.com

Text Pages: 28

Tables: 2

Figures: 6

References: 35

Words in Abstract: 210

Words in Introduction: 485

Words in Discussion: 708

Non-standard abbreviations: Androgen Receptor (AR), Mineralocorticoid Receptor (MR), Glucocorticoid Receptor (GR), Estrogen Receptor (ER), Progesterone Receptor

PR), Farnesoid X Receptor (FXR), Guggulsterone (GS), Peroxisome Proliferator-

Activated Receptor (PPAR), Thyroid Hormone Receptor (TR), Liver X Receptor (LXR),

Tyrosine amino transferase (TAT) 


\section{MOL 7054}

\section{Abstract}

Guggulsterone (GS) is the active substance in guggulipid, an extract of the guggul tree Commiphora mukul used to treat a variety of disorders in humans including dyslipidemia, obestity, and inflammation. The activity of GS has been suggested to be mediated by antagonism of the receptor for bile acids, the farnesoid X receptor (FXR). Here we demonstrate that both stereoisomers of the plant sterol, E- and Z-GS, bind to the steroid receptors at a much higher affinity than to FXR. Both stereoisomers bind to the mineralocorticoid receptor (MR) with a $\mathrm{K}_{\mathrm{i}}$ of approximately $35 \mathrm{nM}$, which is greater than 100 times more potent than their affinity for FXR. Both E- and Z-GS also displayed high affinity for other steroid receptors including the androgen (AR), glucocorticoid (GR), and progesterone receptors (PR) with $\mathrm{K}_{\mathrm{i}} \mathrm{s}$ ranging from $224 \mathrm{nM}$ to $315 \mathrm{nM}$. In cell-based functional cotransfection assays, GSs behaved as antagonists of AR, GR, and MR, but as agonists of PR. Agonist activity was also demonstrated with $\mathrm{ER} \alpha$, however the potency was very low $\left(\mathrm{EC}_{50}>5000 \mathrm{nM}\right)$. In addition, GS displayed activity in functional assays in cell lines expressing endogenous AR, GR, ER, and PR. These data suggest that the variety of pharmacological effects exhibited by GS may be mediated by targeting several steroid receptors. 
Molecular Pharmacology Fast Forward. Published on December 15, 2004 as DOI: 10.1124/mol.104.007054

This article has not been copyedited and formatted. The final version may differ from this version.

MOL 7054

\section{Introduction}

Resin of the gum of the Guggul tree, Commiphora mukul, has been used in Ayurvedic medicine to treat a variety of diseases for several thousand years (Urizar and Moore, 2003). The active substances from the resin have been demonstrated to be the plant sterols, E- and Z-GS (Beg et al., 1996) and the ethyl acetate extract of the resin, which is enriched for these plant sterols is currently available as an over-the-counter herbal remedy, gugulipid. Although guggulipid has been suggested to have beneficial effects for the treatment of dyslipidemia, obesity, arthritis, and inflammation animal and clinical efficacy data has focused primarily on the effects on lipid metabolism. A number of studies, both in animal models and human clinical trials, have shown that guggulipid has beneficial effects on serum lipoprotein profiles models (Agarwal et al., 1986; Chander et al., 1996; Nityanand et al., 1989; Satyavati et al., 1969; Singh et al., 1994).

Two recent studies suggest that GSs exert their hypolipidemic activity via antagonism of the farnesoid X receptor (FXR; NR1H4), a nuclear hormone receptor that functions as a receptor for bile acids (Urizar et al., 2002; Wu et al., 2002). Despite the fact that GS displayed relatively low potency antagonism for FXR, this receptor has been shown to play an essential role in cholesterol and fatty acid homeostatis in addition to its role in bile acid metabolism suggesting a possible mechanism of action (Francis et al., 2003). However, at least two lines of evidence conflict with the hypothesis that the hypolipidemic effects of GS are mediated by FXR. Firstly, the FXR null mice display increased serum total cholesterol, triglyceride, and phospholipid levels (Sinal et al., 2000), which is inconsistent with antagonism of this receptor exhibiting beneficial effects on lipid metabolism. Secondly, consistent with the FXR null mice, a selective synthetic 
MOL 7054

FXR agonist (GW4064) decreases plasma triglycerides and increases plasma HDL levels in rats (Maloney et al., 2000; Willson et al., 2001). Thus, it becomes apparent that the pharmacological effects of GS may be mediated via additional pathways.

Previous studies demonstrated that GS also activates the pregnane $\mathrm{X}$ receptor (PXR; NR1I2), a nuclear receptor that functions as a xenobiotic receptor (Brobst et al., 2004; Wu et al., 2002). However, this is not unusual given the promiscuity of PXR and would not explain the pharmacological effects of GS given the number of compounds that activate this receptor that lack the activity of GS. Recently Brobst et al., using a cotransfection assay, described the ability of GS to activate the progesterone receptor (PR; NR3C3) and estrogen receptor $\alpha$ (ER $\alpha$; NR3A1) (Brobst et al., 2004) indicating that GS may be more promiscuous than originally expected. In the current study, we found that both E- and Z-GS are potent steroid receptor ligands binding to the androgen receptor (AR; NR3C4), mineralocorticoid receptor (MR; NR3C2), glucocorticoid receptor (GR; NR3C1) and PR at affinities as much as 100 times greater than the affinity for FXR. Functionally, GS primarily function as an antagonist of these receptors with the exception of PR where it behaves as a partial agonist. Thus, the wide range of activities that GS has been purported to display may be due to polypharmacological effects targeting the steroid receptor subclass of the nuclear receptor superfamily. 
Molecular Pharmacology Fast Forward. Published on December 15, 2004 as DOI: 10.1124/mol.104.007054

This article has not been copyedited and formatted. The final version may differ from this version.

MOL 7054

\section{Materials and Methods}

Radioligand binding assays

Radioligand binding assays were performed using either the charcoal separation or scintillation proximity technology as previously described (Bramlett et al., 2003; Palmer et al., 2000). Tritiated radioligands were used for all assays with the exception of TR and included dexamethasone (GR), methyltrienolone (R1881) (AR), aldosterone (MR), promegestone (R5020) (PR), GW4064 (FXR), T1317 (LXR $\alpha$ ), 9-cis retinoic acid (RXR), 17 $\beta$-estradiol (ER), PPAR $\alpha$ and PPAR $\delta$ (LY427697) and PPAR $\gamma(L Y 509547)$ (Brooks et al., 2001; Xu et al., 2004). Iodinated triiodothyronine was utilized for TR $\alpha$ and TR $\beta$. Radioligands were purchased from Amersham Biosciences (Piscataway, NJ). E- and ZGS were evaluated in each assay with 10 concentration point displacement curves. Assays were performed with each receptor a minimum of 3 independent times and the $\mathrm{K}_{\mathrm{i}}$ was determined using the Cheng and Prusoff equation following determination of the $\mathrm{IC}_{50}$ by fitting the curve to a four-parameter logistical equation.

\section{Cell based transfection assays}

Human embryonic kidney HEK293 cells or C2C12 cells were co-transfected using Fugene reagent (Roche, Indianapolis, IN). A reporter plasmid containing two copies of probasin ARE (GGTTCTTGGAGTACT) and TK promoter upstream of the luciferase reporter cDNA, was transfected with a plasmid constitutively expressing hAR using viral CMV promoter. A reporter plasmid containing two copies of GRE (TGTACAGGATGTTCT) and TK promoter upstream of the luciferase reporter cDNA, was transfected with a plasmid constitutively expressing either hGR, hMR, or hPR, using 
Molecular Pharmacology Fast Forward. Published on December 15, 2004 as DOI: 10.1124/mol.104.007054

This article has not been copyedited and formatted. The final version may differ from this version.

MOL 7054

viral CMV promoter. A reporter plasmid containing 5 copies of the Gal4 UAS upstream of luciferase was utilized in transfections where the Gal4-AR chimeric receptor was used. The Gal4-AR chimeric receptor was created by replacing the endogenous AR DNA binding domain with the Gal4 DNA binding domain thus leaving the AF-1 and AF-2 regions of AR intact. The reporter plasmid for FXR contained 3 copies of the IR1 element derived from the phospholipid transfer protein promoter (Urizar et al., 2000) upstream of a minimal promoter upstream of luciferase and was tranfected into cells along with hFXR under the control of the CMV promoter. Cells were transfected in T150 $\mathrm{cm}^{2}$ flasks in DMEM media with $5 \%$ charcoal-stripped Fetal Bovine Serum (FBS). After a overnight incubation, transfected cells were trypsinized, plated in 96 well dishes in DMEM media containing 5\% charcoal-stripped FBS, incubated for $4 \mathrm{~h}$ and then exposed to test compounds. Transfection assays for ER $\alpha$ and ER $\beta$ were performed in PC3 human prostatic adenocarcinoma cells grown in RPMI 1640 (without phenol red) with $10 \%$ heat inactivated FBS, $1 \mathrm{mM}$ hepes (Gibco), 100 units penicillin, and $100 \mathrm{~g} / \mathrm{ml}$ streptomycin. The PC-3 cells were transiently transfected using Fugene transfection reagent along with full-length $\mathrm{hER} \alpha$ or $\mathrm{hER} \beta$ in pCMV vectors and an ERE-tkLUC reporter vector. In the antagonist assays low concentrations of agonist for each respective receptors were added to the media $(0.25 \mathrm{nM}$ dexamethasone for $\mathrm{GR}, 0.3 \mathrm{nM}$ of methyltrienolone for $\mathrm{AR}, 0.05$ $\mathrm{nM}$ of progesterone for $\mathrm{PR}, 0.05 \mathrm{nM}$ aldosterone for $\mathrm{MR}$, and $0.1 \mathrm{nM} 17 \beta$-estradiol for ER). After $24 \mathrm{~h}$ of incubations with compounds, cells were lysed and luciferase activity was determined. Data was fit to a four-parameter logistical equation to determine $\mathrm{EC}_{50} / \mathrm{IC}_{50}$ values. The $\%$ efficacy was determined versus maximum stimulation obtained with $100 \mathrm{nM}$ methyltrienolone for AR assay, with $30 \mathrm{nM}$ progesterone for PR assay, with 
MOL 7054

$30 \mathrm{nM}$ aldosterone for MR assay, with $100 \mathrm{nM}$ dexamethasone for GR assay, with 100 $\mathrm{nM}$ estradiol for $\mathrm{ER} \alpha$ and ER $\beta$, and with $1 \mu \mathrm{M}$ GW4064 for FXR. Assays were performed a minimum of 3 times for each receptor in both the agonist and antagonist formats.

\section{Steroid receptor functional assays}

TAT mRNA was measured using branched chain-DNA (bDNA; Quantigene ${ }^{\text {) }}$ ) as previously described (Burris et al., 1999). The branched chain-DNA (bDNA; Quantigene ${ }^{\circledR)}$ ) assay for TAT mRNA was performed according to the manufacturer's protocol (Genospectra, Fremont, CA). For Quantigene® TAT mRNA measurement in H4IIE cells, cells were seeded in 96 well plates at 25,000 cells per well in DMEM with $10 \%$ FBS and allowed to attached overnight. The following day cell media was replaced with serum free DMEM and serum starved for 24 hours prior to treatment with dexamethasone, E-guggulsterone, Z-guggulsterone, or RU486 for 24 hours. At the conclusion of treatment, cells were lysed with $50 \mu$ lysis buffer (provided by Genospectra). After a 15 minute incubation at $37^{\circ} \mathrm{C}, 50 \mu \mathrm{l}$ of the lysate from each well was added to capture plates (provided by Genospectra) containing either rGAPDH or rTAT-specific oligonucleotides in $50 \mu \mathrm{l}$ of lysis buffer totaling $100 \mu \mathrm{l}$. The capture plate was sealed and incubated overnight at $53^{\circ} \mathrm{C}$ in a Fisher Labline plate incubator. After overnight incubation, the bDNA and label probes were annealed as directed by the manufacturer. Finally, upon addition of luminescent alkaline phophatase substrate, dioxitane, luminescence was quantitated using a Packard TopCount microplate scintillation and luminescence counter. 
Molecular Pharmacology Fast Forward. Published on December 15, 2004 as DOI: 10.1124/mol.104.007054

This article has not been copyedited and formatted. The final version may differ from this version.

MOL 7054

T-47D cells (ATCC, Manassa, VA) were maintained in RPMI 1640 media (Invitrogen Carlsbad, CA) with 10\% FBS, 1\% MEM non-essential amino acids (Invitrogen), 1\% sodium pyruvate (Invitrogen) and 1\% antibiotic/antimycotic (Invitrogen). Cells were trypsinized and seeded into 96-well plates at a density of 20,000 cells/well in culture media containing 10\% charcoal/dextran treated, heat-inactivated FBS (Hyclone, Logan, UT) and allowed to attach overnight. To evaluate agonist or antagonist activity, compounds were tested in the absence or presence of $0.25 \mathrm{nM}$ promegesterone $(\mathrm{R} 5020$, NEN, Boston, MA). Following 24 h of treatment the cells were washed with Dulbecco's PBS (Invitrogen), all liquid was removed, and plates were frozen at $-80^{\circ} \mathrm{C}$ overnight. Alkaline phosphatase activity was evaluated using the 1-Step PNPP assay (Pierce, Rockford, IL).

Human prostate cancer LNCaP cells were seeded into 96-well culture plates at 20,000 cells/well in DMEM-F12 (3:1) (Invitrogen) supplemented with 5\% charcoal stripped serum (Hyclone), 1\% penicillin/streptomycin, 1\% HEPES buffer, and 1\% L-glutamine. The following day cells were treated with compounds for 48 hours. R1881 was used as a standard AR agonist and relative efficacy of GS was calculated based on the maximal efficacy of R1881 (Bonne and Raynaud, 1975). Following treatment, $5 \mu 1 /$ well of the media was removed and assayed for the presence of human prostate specific antigen by ELISA according to the manufacturer's protocol (Diagnostic Systems Laboratories, Inc., Webster, TX).

The MCF-7 breast adenocarcinoma cell line proliferation assay for estrogen activity was performed as previously described (Dodge et al., 1996). 
Molecular Pharmacology Fast Forward. Published on December 15, 2004 as DOI: 10.1124/mol.104.007054

This article has not been copyedited and formatted. The final version may differ from this version.

MOL 7054

\section{Results}

GS has previously been reported to be a specific FXR antagonist (Urizar et al., 2002; Wu et al., 2002); however, we noted upon analysis of its effect on FXR target genes that additional pharmacological activity might be associated with GS. The steroidal structure of GS (Fig. 1) suggested that its ability to bind to steroid receptors should be examined. Radioligand binding assays for all the steroid receptors within the nuclear receptor superfamily (AR, GR, PR, MR, ER $\alpha$, and ER $\beta$ ) were performed and indicated that both stereoisomers of GS (E-GS and Z-GS) display high affinity for AR, GR, MR, and PR relative to FXR (Table 1). The affinity of E-GS and Z-GS for the steroid receptors was impressive considering that both stereoisomers bound to MR with greater than 125 -fold selectivity vs. FXR while the selectivity for AR, GR, and PR vs. FXR was greater than 20-fold. No significant stereoisomer selectivity was detected for any of the receptors. Clearly the highest affinity for GS was against MR with a $\mathrm{K}_{\mathrm{i}}$ of 37-39 nM while affinity constants for AR, GR, and PR were in the 200-320 nM range. GS was able to displace a radiolabeled FXR ligand, however it required significantly greater than 5,000 nM GS for this to occur and never reached 50\% displacement even at concentrations reaching 40,000 nM. Radioligand binding assays were also performed for a variety of other nuclear hormone receptors including the liver $\mathrm{X}$ receptor $\alpha(\operatorname{LXR} \alpha)$, thyroid hormone receptor $\alpha$ (TR $\alpha), \operatorname{TR} \beta$, peroxisome proliferator-activated receptor $\alpha(\operatorname{PPAR} \alpha), \operatorname{PPAR} \delta, \operatorname{PPAR} \gamma$ and the retinoid $\mathrm{X}$ receptor $\alpha(\mathrm{RXR} \alpha)$. No significant binding was detected for any of these receptors (Table 1$)$.

The radioligand binding data suggest that both E- and Z-GS display broad-spectrum steroid receptor binding activity. In order to investigate the functional significance of the 
Molecular Pharmacology Fast Forward. Published on December 15, 2004 as DOI: 10.1124/mol.104.007054

This article has not been copyedited and formatted. The final version may differ from this version.

MOL 7054

binding activity, we assessed the activity of both GS stereoisomers in cell based functional assays in which we coexpressed AR, GR, MR, or PR in HEK293 cells along with a luciferase reporter under the direction of a promoter with multiple copies of a steroid receptor response element inserted. Both GS stereoisomers were tested in agonist and antagonist format. As illustrated in figure 2, both E- and Z-GS antagonized AR, GR, and MR. GS was most potent targeting AR, which Z-GS antagonized with an $\mathrm{IC}_{50}$ of 220 $\mathrm{nM}$ (Table 2). The activity of GS against GR and MR was significantly less with $\mathrm{IC}_{50} \mathrm{~S}$ generally in the 1-2 $\mu \mathrm{M}$ range. Z-GS displayed greater potency than E-GS for AR, GR, and MR in the cell based assay. Although E- and Z-GS were antagonists of AR, GR, and MR, both stereoisomers behaved as partial agonists of PR. As shown in figure $2 \mathrm{~B} \& \mathrm{D}$, both stereoisomers increased reporter expression with $\mathrm{EC}_{50} \mathrm{~S}$ ranging from 740 to 1200 nM. Maximal efficacy (vs. progesterone) for both stereoisomers was 63-64\%. Agonist activity was also detected for $\mathrm{ER} \alpha$ and $\mathrm{ER} \beta$ in transfected PC3 cells; however, the $\mathrm{EC}_{50}$ was greater than 5,000 $\mathrm{nM}$. At the highest concentration tested $(10 \mu \mathrm{M})$ GS displayed selectivity for ER $\alpha$ (maximal efficacy $41-59 \%$ vs. $17 \beta$-estradiol) vs. ER $\beta$ (6-15\% vs. 17ß-estradiol) (Table 2).

To confirm the functional activity of GS as a steroid receptor ligand, we assessed the activity of both GS stereoisomers in several cell lines endogenously expressing GR, AR, PR, or ER. The ability of GS stereoisomers to affect expression of a GR regulated gene, tyrosine amino-transferase (TAT), was examined in the H4IIE hepatocarcinoma cell line. TAT is a well-characterized glucocorticoid responsive gene directly responsive to GR via a glucocorticoid response element located in its promoter (Jantzen et al., 1987). As illustrated in figure $3 \mathrm{~A}$ and $\mathrm{B}$, the GR agonist dexamethasone increased expression of 
Molecular Pharmacology Fast Forward. Published on December 15, 2004 as DOI: 10.1124/mol.104.007054

This article has not been copyedited and formatted. The final version may differ from this version.

MOL 7054

TAT mRNA 5-6 fold whereas either E- or Z-GS alone did not affect TAT expression. However, either E- or Z-GS effectively antagonized the activity of dexamethasone. As was the case for the other cell based assays, the potency of E- and Z-GS was lower than indicated by the radioligand binding assay; however, both the transfection assay and TAT expression assay indicated single digit $\mu \mathrm{M}$ potency $\left(\mathrm{EC}_{50} \mathrm{E}-\mathrm{GS}=3.0 \mu \mathrm{M} ; \mathrm{EC}_{50} \mathrm{Z}-\mathrm{GS}=9.9\right.$ $\mu \mathrm{M})$.

Also consistent with the transfection results, assessment of activity of E- and Z-GS in the MCF-7 breast adenocarcima cell proliferation assay for estrogen activity indicated that both stereoisomers were weak agonists with Z-GS providing significantly more activity than E-GS (Fig 4). The activity of both E- and Z-GS was blocked by the selective ER antagonist, ICI 182,780, in these cells (Fig. 4 inset). AR activity was confirmed first in the LNCaP human prostate cancer cell line. Expression of prostate specific antigen (PSA) protein was used to monitor AR activity since PSA is directly responsive to AR action via androgen response elements localized in the promoter of the gene (Cleutjens et al., 1996; Luke and Coffey, 1994; Murtha et al., 1993). As shown in figure 5A, both Eand Z-GS stimulated PSA expression in LNCaP cells. This is in contrast to the cell based transfection assay where both GS stereoisomers antagonized AR activity. However, LNCaP cells have been shown to respond to both AR agonists and antagonists by increasing PSA expression (Wolf et al., 1992). The potency of induction of PSA expression in the $\mathrm{LNCaP}$ cells $\left(\mathrm{EC}_{50}(\mathrm{Z}-\mathrm{GS})=260 \mathrm{nM} ; \mathrm{EC}_{50}(\mathrm{E}-\mathrm{GS})=550 \mathrm{nM}\right)$ was consistent with potency in cell based transfection assays (Table 2). An AR antagonist that retains the ability to block AR activity in the LNCap cells, bicalutamide, was able to suppress the agonist activity of both GS stereoisomers indicating that the effect is 
Molecular Pharmacology Fast Forward. Published on December 15, 2004 as DOI: 10.1124/mol.104.007054

This article has not been copyedited and formatted. The final version may differ from this version.

MOL 7054

mediated by AR (Fig. 5A inset). In order to further examine the functional AR activity of the GSs, we tested their activity in two additional assay systems. We created a chimeric AR protein by replacing the wild-type AR DNA binding domain with that of the yeast transcription factor, GAL4. This chimeric AR retained the AF-1 domain amino-terminal to the GAL4 DNA binding domain and the AF-2 domain carboxy-terminal to the GAL4 replacement. This chimeric receptor was then utilized in a cotransfection system in HEK293 cells along with a reporter containing 5 copies of a GAL4 UAS upstream of luciferase. As shown in Fig. 5B, both GSs effectively antagonized the activity of the AR

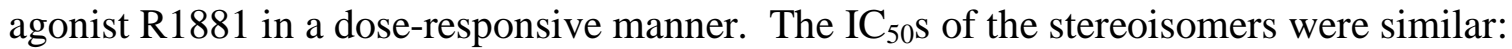
E-GS $\mathrm{IC}_{50}=1.0 \mu \mathrm{M}$ and Z-GS $\mathrm{IC}_{50}=1.5 \mu \mathrm{M}$. We also examined the activity of the GSs using identical constructs as those utilized in the HEK293 cell cotransfections, but transfecting $\mathrm{C} 2 \mathrm{C} 12$ cells instead. Both GSs displayed the ability to antagonize the activity of the R1881; however, the $\mathrm{C} 2 \mathrm{C} 12$ cells appeared to be less sensitive with the $\mathrm{IC}_{50} \mathrm{~S}$ of GSs near $10 \mu \mathrm{M}$. Thus, these additional models confirm the AR antagonist activity of the GSs.

Induction of alkaline phosphatase activity in the T-47D breast cancer cell line is a commonly used assay to assess the activity of compounds with PR activity (Palmer et al., 2000). Thus, we utilized this assay to assess the activity of both E- and Z-GS in a cell line expressing endogenous levels of PR. As shown in figure 6, both E- and Z-GS functioned as PR agonists inducing alkaline phosphatase activity. Maximal induction for both stereoisomers was in the range of $80 \%$ of the maximal level induced by the PR agonist, R5020. The potencies of the stereoisomers was consistent with that found in the cell-based transfection experiments. Z-GS displayed an $\mathrm{EC}_{50}$ of $1.6 \mu \mathrm{M}$ while $\mathrm{E}-\mathrm{GS}$ 
Molecular Pharmacology Fast Forward. Published on December 15, 2004 as DOI: 10.1124/mol.104.007054

This article has not been copyedited and formatted. The final version may differ from this version.

\section{MOL 7054}

displayed an $\mathrm{EC}_{50}$ of $1.2 \mu \mathrm{M}$. The activity of both stereoisomers was blocked by the PR antagonist, RU486 (Fig. 6 inset). No antagonist activity for either stereoisomer was detected in this assay (data not shown). 
Molecular Pharmacology Fast Forward. Published on December 15, 2004 as DOI: 10.1124/mol.104.007054

This article has not been copyedited and formatted. The final version may differ from this version.

MOL 7054

\section{Discussion}

The plant sterols, E- and Z-GS, have been identified as the active agents in guggulipid (Beg et al., 1996; Satyavati, 1988), which is an ethyl acetate extract from the gum resin of the tree Commiphora mukul. An agent derived from gugglu (gum resin of Commiphora mukul) used in ancient Ayurvedic medicine, guggulipid has been shown to have activity as a hypolipidemic agent both in animal models (Chander et al., 1996; Satyavati et al., 1969; Urizar and Moore, 2003) and in humans (Agarwal et al., 1986; Nityanand et al., 1989; Singh et al., 1994; Urizar and Moore, 2003). Although the efficacy of guggulipid has met with some recent controversy (Firenzuoli and Gori, 2003; Karuparthy and Vepachedu, 2003; Szapary et al., 2003), it is commonly used in India for treatment of hyperlipidemia and obesity and is widely available worldwide as an herbal dietary supplement.

The pharmacological activity of GS has been suggested to be mediated by the nuclear hormone receptor FXR based its ability to antagonize this receptor (Urizar et al., 2002; Wu et al., 2002). Z-GS has been shown to antagonize the activity of either a natural bile acid ligand (chenodeoxycholic acid (CDCA)) or a synthetic one (GW4064) in cell-based cotransfection assays as well as in FXR target gene induction assays in primary hepatocytes and in the Caco-2 and HepG2 cell lines (Urizar et al., 2002; Wu et al., 2002). In addition, both studies demonstrated that GS antagonizes coactivator recruitment in biochemical assays indicating that GS is a direct FXR ligand, albeit a weak one with an $\mathrm{IC}_{50}$ in the range of 5-50 $\mu \mathrm{M}$ (Cui et al., 2003; Urizar et al., 2002; Wu et al., 2002). A very recent study indicated that GS activates Gal4-DNA binding domain PR and ER $\alpha$ ligand binding domain chimeric receptors in a cell based cotransfection assay 
Molecular Pharmacology Fast Forward. Published on December 15, 2004 as DOI: 10.1124/mol.104.007054

This article has not been copyedited and formatted. The final version may differ from this version.

MOL 7054

(Brobst et al., 2004). Our analysis of the activity of GS confirms this, but also provides significant insight into the broad steroid receptor binding activity that is likely associated with the pharmacological activity of this unique natural product. Profiling of both stereoisomers of GS in radioligand binding assays for a wide range of nuclear receptors indicated that the primary targets for the natural product were the steroid receptors: AR, GR, MR, and PR. The GSs bound to MR with the highest affinity with $\mathrm{K}_{\mathrm{i}} \mathrm{s}$ in the $35 \mathrm{nM}$ range while the $\mathrm{K}_{\mathrm{i}} \mathrm{s}$ for $\mathrm{AR}, \mathrm{GR}$ and $\mathrm{PR}$ were all in the 200-320 nM range. A radioligand binding assay for FXR indicated that the GSs behaved as FXR ligands but did not displace radiolabeled GW4064 until concentrations well beyond 5,000 nM. Thus, GSs display significant selectivity for the steroid receptors over FXR in the range of $>20-125$ fold. Functional analysis of E- and Z-GS in cell-based assays demonstrated that the natural product antagonizes MR, GR, and AR while activating PR. Consistent with Brobst et al. (Brobst et al., 2004), ER agonist activity was also detected in 2 functional assays one of which suggests ER $\alpha$ selectivity although the potency was very low.

Thus, both E- and Z-GS function as antagonists of MR, GR, and AR and agonists of PR at concentrations well below those required to block FXR indicating that the actions of GS may be due to a polypharmacological profile of activity targeting the steroid receptor members of the nuclear hormone receptor superfamily in addition to FXR. Nuclear receptors such as FXR require significantly higher levels of their natural ligands (micromolar levels) for activation than do the steroid receptors (nanomolar levels). However, based on our data indicating that GSs display considerably higher affinity for several steroid receptors than for FXR, it is reasonable to assume that doses of GS required to act on FXR in vivo would be well above those required to affect steroid 
MOL 7054

receptor activity. Much of the activity that we have characterized for the GSs is consistent with the clinical pharmacology associated with its use. Clearly compounds with similar steroid receptor agonist/antagonist profiles such as cyproterone acetate, which functions as an $\mathrm{AR}$ and GR antagonist and PR agonist have been demonstrated to have hypolipidemic activity (Damgaard-Pedersen and Fogh, 1980; Wallentin and Varenhorst, 1980). Similary, spironolactone that functions as a MR and GR antagonist and PR agonist has been demonstrated to have beneficial effects on hypertension and congestive heart failure (Pitt et al., 1999). In addition, there are a variety of other pharmacological activities that have been associated with guggulipid use such as reduction of acne (Urizar and Moore, 2003), which based on our data may be associated with the antiandrogen activity of the GSs. The range of receptors targeted by the GSs indicates that the pharmacology of these plant sterols will require greater examination in order to understand their activity and clinical significance. 


\section{MOL 7054}

\section{References}

Agarwal RC, Singh SP, Saran RK, Das SK, Sinha N, Asthana OP, Gupta PP, Nityanand S, Dhawan BN and Agarwal SS (1986) Clinical-Trial of Gugulipid a New Hypolipidemic Agent of Plant- Origin in Primary Hyperlipidemia. Indian J Med Res 84:626-634.

Beg M, Singhal KC and Afzaal S (1996) A study of effect of guggulsterone on hyperlipidemia of secondary glomerulopathy. Indian J Physiol Pharmacol 40(3):237-240.

Bonne C and Raynaud JP (1975) Methyltrienolone, a specific ligand for cellular androgen receptors. Steroids 26(2):227-232.

Bramlett KS, Houck KA, Borchert KM, Dowless MS, Kulanthaivel P, Zhang Y, Beyer TP, Schmidt R, Thomas JS, Michael LF, Barr R, Montrose C, Eacho PI, Cao G and Burris TP (2003) A natural product ligand of the oxysterol receptor, liver X receptor. J Pharmacol Exp Ther 307(1):291-296.

Brobst DE, Ding X, Creech KL, Goodwin B, Kelley B and Staudinger JL (2004) Guggulsterone Activates Multiple Nuclear Receptors and Induces CYP3A Gene Expression through the Pregnane X Receptor. J Pharmacol Exp Ther 310(2):528535.

Brooks DA, Etgen GJ, Rito CJ, Shuker AJ, Dominianni SJ, Warshawsky AM, Ardecky R, Paterniti JR, Tyhonas J, Karanewsky DS, Kauffman RF, Broderick CL, Oldham BA, Montrose-Rafizadeh C, Winneroski LL, Faul MM and McCarthy JR (2001) Design and synthesis of 2-methyl-2-\{4-[2-(5-methyl-2-aryloxazol-4- 
Molecular Pharmacology Fast Forward. Published on December 15, 2004 as DOI: 10.1124/mol.104.007054

This article has not been copyedited and formatted. The final version may differ from this version.

MOL 7054

yl)ethoxy]phenoxy\}propionic acids: A new class of dual PPAR alpha/gamma agonists. J Med Chem 44(13):2061-2064.

Burris TP, Pelton PD, Zhou LB, Osborne MC, Cryan E and Demarest KT (1999) A novel method for analysis of nuclear receptor function at natural promoters: Peroxisome proliferator-activated receptor gamma agonist actions on aP2 gene expression detected using branched DNA messenger RNA quantitation. Mol Endocrinol 13(3):410-417.

Chander R, Khanna AK and Kapoor NK (1996) Lipid lowering activity of guggulsterone from Commiphora mukul in hyperlipaemic rats. Phytotherapy Research 10(6):508-511.

Cleutjens K, vanEekelen C, vanderKorput H, Brinkmann AO and Trapman J (1996) Two androgen response regions cooperate in steroid hormone regulated activity of the prostate-specific antigen promoter. J Biol Chem 271(11):6379-6388.

Cui J, Huang L, Zhao A, Lew J-L, Yu J, Sahoo S, Meinke PT, Royo I, Pelaez F and Wright SD (2003) Guggulsterone Is a Farnesoid X Receptor Antagonist in Coactivator Association Assays but Acts to Enhance Transcription of Bile Salt Export Pump. J Biol Chem 278(12):10214-10220.

Damgaard-Pedersen F and Fogh M (1980) The effect of cyproterone acetate on serum lipids in normal men. Acta Endocrinol (Copenh) 94(2):280-283.

Dodge JA, Glasebrook AL, Magee DE, Phillips DL, Sato M, Short LL and Bryant HU (1996) Environmental estrogens: Effects on cholesterol lowering and bone in the ovariectomized rat. J Steroid Biochem Mol Biol 59(2):155-161. 


\section{MOL 7054}

Firenzuoli F and Gori L (2003) Guggulipid and cholesterol levels. Jama 290(21):2800; author reply 2801.

Francis GA, Fayard E, Picard F and Auwerx J (2003) Nuclear receptors and the control of metabolism. Annu Rev Physiol 65:261-311. Epub 2002 May 2001.

Jantzen HM, Strahle U, Gloss B, Stewart F, Schmid W, Boshart M, Miksicek R and Schutz G (1987) Cooperativity of Glucocorticoid Response Elements Located Far Upstream of the Tyrosine Aminotransferase Gene. Cell 49(1):29-38.

Karuparthy VR and Vepachedu S (2003) Guggulipid and cholesterol levels. Jama 290(21):2800-2801; author reply 2801 .

Luke MC and Coffey DS (1994) Human Androgen Receptor-Binding to the Androgen Response Element of Prostate-Specific Antigen. Journal of Andrology 15(1):4151.

Maloney PR, Parks DJ, Haffner CD, Fivush AM, Chandra G, Plunket KD, Creech KL, Moore LB, Wilson JG, Lewis MC, Jones SA and Willson TM (2000) Identification of a chemical tool for the orphan nuclear receptor FXR. J Med Chem 43(16):2971-2974.

Murtha P, Tindall DJ and Young CYF (1993) Androgen Induction of a Human ProstateSpecific Kallikrein, Hklk2 - Characterization of an Androgen Response Element in the 5' Promoter Region of the Gene. Biochemistry 32(25):6459-6464.

Nityanand S, Srivastava JS and Asthana OP (1989) Clinical trials with gugulipid. A new hypolipidaemic agent. J Assoc Physicians India 37(5):323-328.

Palmer S, Campen CA, Allan GF, Rybczynski P, Haynes-Johnson D, Hutchins A, Kraft P, Kiddoe M, Lai M-T and Lombardi E (2000) Nonsteroidal progesterone 
Molecular Pharmacology Fast Forward. Published on December 15, 2004 as DOI: 10.1124/mol.104.007054

This article has not been copyedited and formatted. The final version may differ from this version.

MOL 7054

receptor ligands with unprecedented receptor selectivity. J Steroid Biochem Mol Biol 75(1):33-42.

Pitt B, Zannad F, Remme WJ, Cody R, Castaigne A, Perez A, Palensky J and Wittes J (1999) The effect of spironolactone on morbidity and mortality in patients with severe heart failure. Randomized Aldactone Evaluation Study Investigators. $N$ Engl J Med 341(10):709-717.

Satyavati GV (1988) Gum Guggul (Commiphora-Mukul) - the Success Story of an Ancient Insight Leading to a Modern Discovery. Indian J Med Res 87:327-335.

Satyavati GV, Dwarakanath C and Tripathi SN (1969) Experimental studies on the hypocholesterolemic effect of Commiphora mukul. Engl. (Guggul). Indian J Med Res 57(10):1950-1962.

Sinal CJ, Tohkin M, Miyata M, Ward JM, Lambert G and Gonzalez FJ (2000) Targeted disruption of the nuclear receptor FXR/BAR impairs bile acid and lipid homeostasis. Cell 102(6):731-744.

Singh RB, Niaz MA and Ghosh S (1994) Hypolipidemic and antioxidant effects of Commiphora mukul as an adjunct to dietary therapy in patients with hypercholesterolemia. Cardiovasc Drugs Ther 8(4):659-664.

Szapary PO, Wolfe ML, Bloedon LT, Cucchiara AJ, DerMarderosian AH, Cirigliano MD and Rader DJ (2003) Guggulipid for the treatment of hypercholesterolemia: a randomized controlled trial. Jama 290(6):765-772.

Urizar NL, Dowhan DH and Moore DD (2000) The farnesoid X-activated receptor mediates bile acid activation of phospholipid transfer protein gene expression. $J$ Biol Chem 275(50):39313-39317. 


\section{MOL 7054}

Urizar NL, Liverman AB, Dodds DT, Silva FV, Ordentlich P, Yan YZ, Gonzalez FJ, Heyman RA, Mangelsdorf DJ and Moore DD (2002) A natural product that lowers cholesterol as an antagonist ligand for FXR. Science 296(5573):17031706.

Urizar NL and Moore DD (2003) GUGULIPID: a natural cholesterol-lowering agent. Annu Rev Nutr 23:303-313. Epub 2003 Feb 2026.

Wallentin L and Varenhorst E (1980) Plasma lipoproteins during treatment with cyproterone acetate in men with prostatic carcinoma. J Clin Endocrinol Metab 51(5):1118-1122.

Willson TM, Jones SA, Moore JT and Kliewer SA (2001) Chemical genomics: Functional analysis of orphan nuclear receptors in the regulation of bile acid metabolism. Medicinal Research Reviews 21(6):513-522.

Wolf DA, Schulz P and Fittler F (1992) Transcriptional Regulation of Prostate Kallikrein-Like Genes by Androgen. Mol Endocrinol 6(5):753-762.

Wu J, Xia CS, Meier J, Li SZ, Hu X and Lala DS (2002) The hypolipidemic natural product guggulsterone acts as an antagonist of the bile acid receptor. Mol Endocrinol 16(7):1590-1597.

Xu YP, Rito CJ, Etgen GJ, Ardecky RJ, Bean JS, Bensch WR, Bosley JR, Broderick CL, Brooks DA, Dominianni SJ, Hahn PJ, Liu S, Mais DE, Montrose-Rafizadeh C, Ogilvie KM, Oldham BA, Peters M, Rungta DK, Shuker AJ, Stephenson GA, Tripp AE, Wilson S, Winneroski LL, Zink R, Kauffman RF and McCarthy JR (2004) Design and synthesis of alpha-aryloxy-alpha-methylhydrocinnamic acids: 
Molecular Pharmacology Fast Forward. Published on December 15, 2004 as DOI: 10.1124/mol.104.007054

This article has not been copyedited and formatted. The final version may differ from this version.

MOL 7054

A novel class of dual peroxisome proliferator-activated receptor alpha/gamma agonists. J Med Chem 47(10):2422-2425. 


\section{MOL 7054}

\section{Figure Legends}

Figure 1. Chemical structure of guggulsterone [4,17(20)-pregnadiene-3,16-dione].

Figure 2. Functional analysis of the activity of E- and Z-GS in HEK293 cells transfected with MR, GR, AR, or MR. A. Z-GS is a MR, GR, AR, and FXR antagonist. HEK293 cells transiently transfected with vectors directing the expression of MR, GR, AR, or FXR and the appropriate reporter vector were treated with a cognate agonist and the ability of Z-GS to antagonize their activity was examined. B. Z-GS is a PR agonist. HEK293 cells transiently transfected with a vector directing the expression of PR and a reporter vector were treated with varying doses of Z-GS. C. E-GS is a MR, GR, AR, and FXR antagonist. HEK293 cells transiently transfected with vectors directing the expression of MR, GR, AR, or FXR and the appropriate reporter vector were treated with a cognate agonist and the ability of E-GS to antagonize their activity was examined. D. E-GS is a PR agonist. HEK293 cells transiently transfected with a vector directing the expression of PR and a reporter vector were treated with varying doses of E-GS. For each receptor a representative of at least three independent experiments is shown. Table 2 provides the potency and efficacy data that includes statistics on all experiments performed. Relative activity reflects the activity relative to induction of activity with a fixed amount of appropriate agonists as described in the materials and methods.

Figure 3. E- and Z-GS antagonize dexamethasone induced TAT expression from H4IIE cells. A. E-GS antagonizes dexamethasone induced TAT expression. H4IIE rat 
MOL 7054

hepatoma cells were treated with either E-GS alone or in the presence of the GR agonist, dexamethasone followed by assessment of TAT mRNA expression. B. Z-GS antagonizes dexamethasone induced TAT expression. H4IIE rat hepatoma cells were treated with either Z-GS alone or in the presence of the GR agonist, dexamethasone followed by assessment of TAT mRNA expression.

Figure 4. E- and Z-GS stimulate MCF-7 breast adenocarcinoma cell line proliferation. MCF-7 cells were treated with various concentrations of E- or Z-GS for $48 \mathrm{~h}$ and proliferation was assessed by $\left[{ }^{3} \mathrm{H}\right]$-thymidine incorporation. Efficacy is indicated as a percentage of stimulation of proliferation relative to maximal stimulation by $17 \beta$ estradiol (E2). The inset illustrates the ability of the specific ER antagonist, ICI 182,780 (1 $\mathrm{nM})$ to inhibit E- and Z-GS induced cellular proliferation.

Figure 5. Functional AR activity of guggulsterones. A) E- and Z-GS stimulate PSA expression in the human prostate cancer cell line, $\mathrm{LNCaP}$. LNCaP cells were treated with E- or Z-GS for $48 \mathrm{~h}$ followed by assessment of PSA secretion by ELISA. Efficacy is indicated as a percentage of stimulation of PSA relative to maximal stimulation by R1881. The inset illustrates the ability of the specific AR antagonist, bicalutamide (2 $\mu \mathrm{M}$ ) to inhibit E- and Z-GS induced PSA expression. B) E- and Z-GS antagonize R1881 stimulated GAL4 reporter activity in HEK293 cells transfected with a GAL4 AR chimeric receptor in which the DNA binding domain of $\mathrm{AR}$ as been replaced with the GAL4 DNA binding domain. Both the AF-1 and AF-2 domains of AR are intact in the 
MOL 7054

chimeric receptor. C) E- and Z-GS antagonize R1881 stimulated ARE reporter activity in $\mathrm{C} 2 \mathrm{C} 12$ cells transfected with wild-type AR.

Figure 6. E- and Z-GS stimulate alkaline phosphatase activity expression in the human breast cancer cell line, T-47D. T-47D cells were treated with E- or Z-GS for $48 \mathrm{~h}$ followed by assessment of alkaline phosphatase activity. Efficacy is indicated as a percentage of maximal stimulation by R5020. The inset illustrates the ability of the the PR antagonist, RU486 (30 nM), to inhibit E- and Z-GS induced alkaline phosphatase activity. 
Table 1. Binding affinities of E- and Z-Guggulsterone to the Steroid Receptors

$\begin{array}{lll}\text { Ki }(\mathrm{nM}) & \text { E-GS } & \text { Z-GS } \\ \text { GR } & 252 \pm 6 & 224 \pm 26 \\ \text { MR } & 37 \pm 2 & 39 \pm 4 \\ \text { AR } & 315 \pm 13 & 240 \pm 21 \\ \text { PR } & 224 \pm 6 & 201 \pm 18 \\ \text { ER } \alpha & >5000 & >5000 \\ \text { ER } \beta & >5000 & >5000 \\ \text { FXR } & >5000 & >5000 \\ \text { LXR } \alpha & >5000 & >5000 \\ \text { TR } \alpha & >5000 & >5000 \\ \text { TR } \beta & >5000 & >5000 \\ \text { PPAR } \alpha & >5000 & >5000 \\ \text { PPAR } \delta & >5000 & >5000 \\ \text { PPAR } \gamma & >5000 & >5000 \\ \text { RXR } \alpha & >5000 & >5000\end{array}$


Table 2. Functional Activity of E- and Z-Guggulsterone in Cotransfection Assays

\begin{tabular}{lllll} 
& \multicolumn{2}{c}{$\mathrm{IC}_{50}(\mathrm{nM})$} & \multicolumn{2}{c}{$\mathrm{EC}_{50}(\mathrm{nM}) /(\% \mathrm{Eff})$} \\
Receptor & E-GS & Z-GS & E-GS & Z-GS \\
GR & $6060 \pm 310$ & $1740 \pm 150$ & $\mathrm{NA}$ & $\mathrm{NA}$ \\
MR & $1880 \pm 390$ & $1000 \pm 310$ & $\mathrm{NA}$ & NA \\
AR & $660 \pm 240$ & $220 \pm 70$ & $\mathrm{NA}$ & NA \\
PR & NA & NA & $740 \pm 220(63 \%)$ & $1200(64 \%)$ \\
ER $\alpha$ & NA & NA & $>5000(41 \%)$ & $>5000(59 \%)$ \\
ER $\beta$ & NA & NA & $>5000(6 \%)$ & $>5000(15 \%)$ \\
FXR & $>50,000$ & $>50,000$ & NA & NA
\end{tabular}


Figure 1

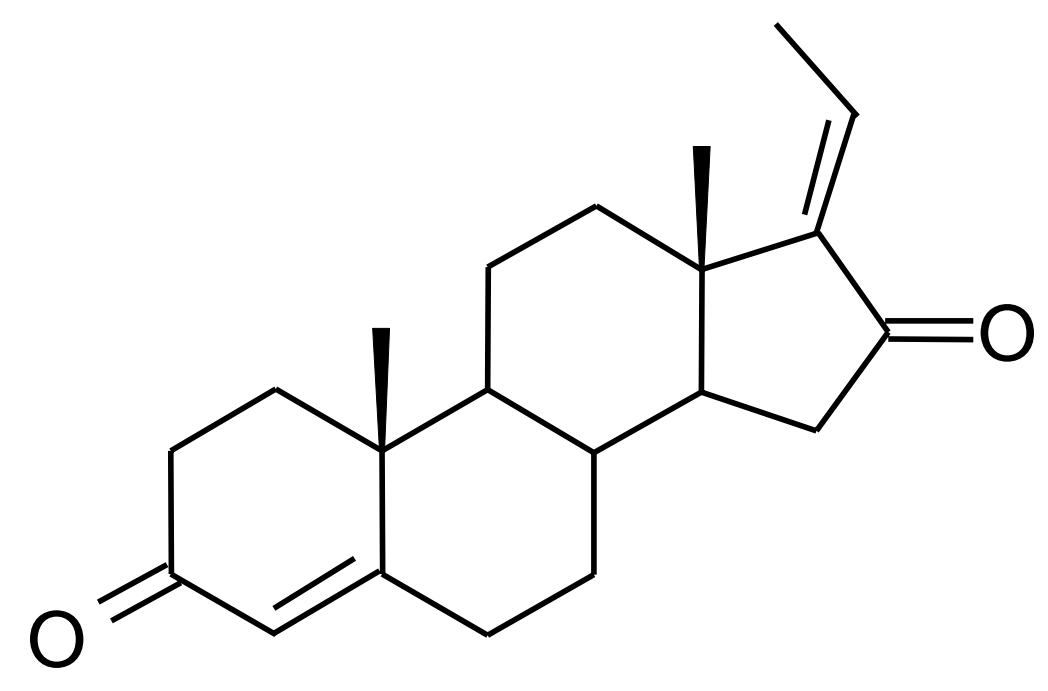

Guggulsterone 
Figure 2
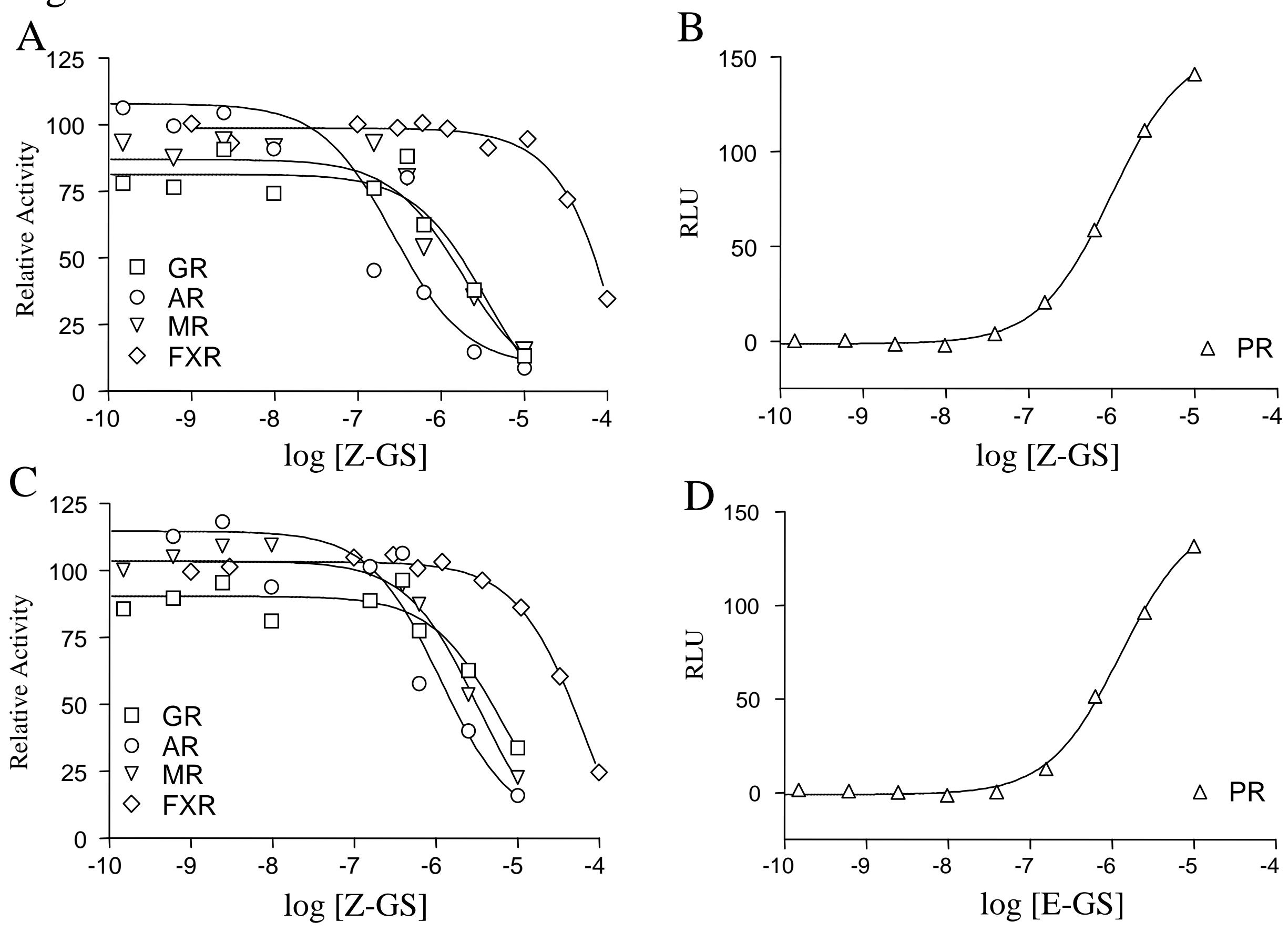
Figure 3
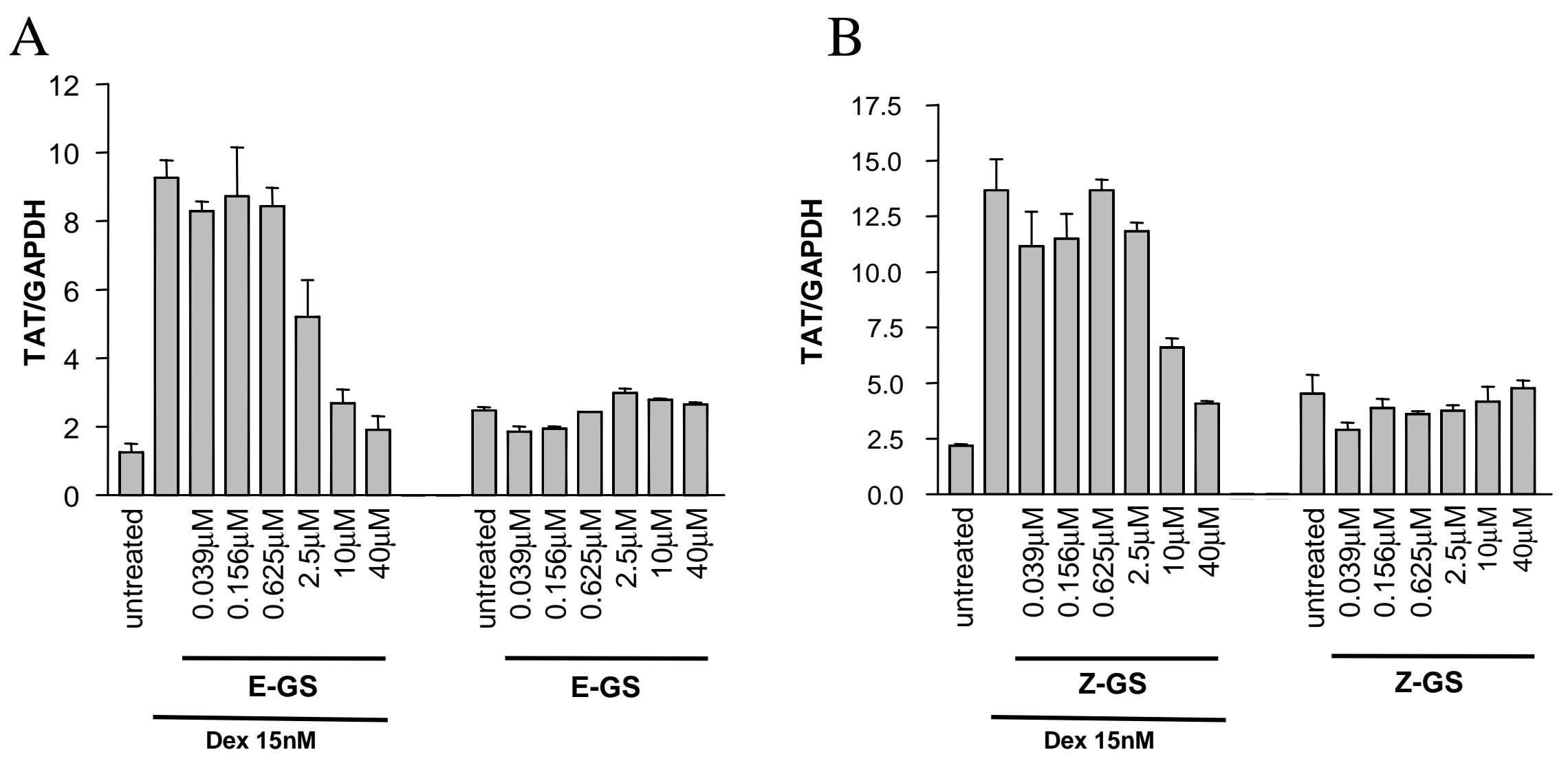
Figure 4

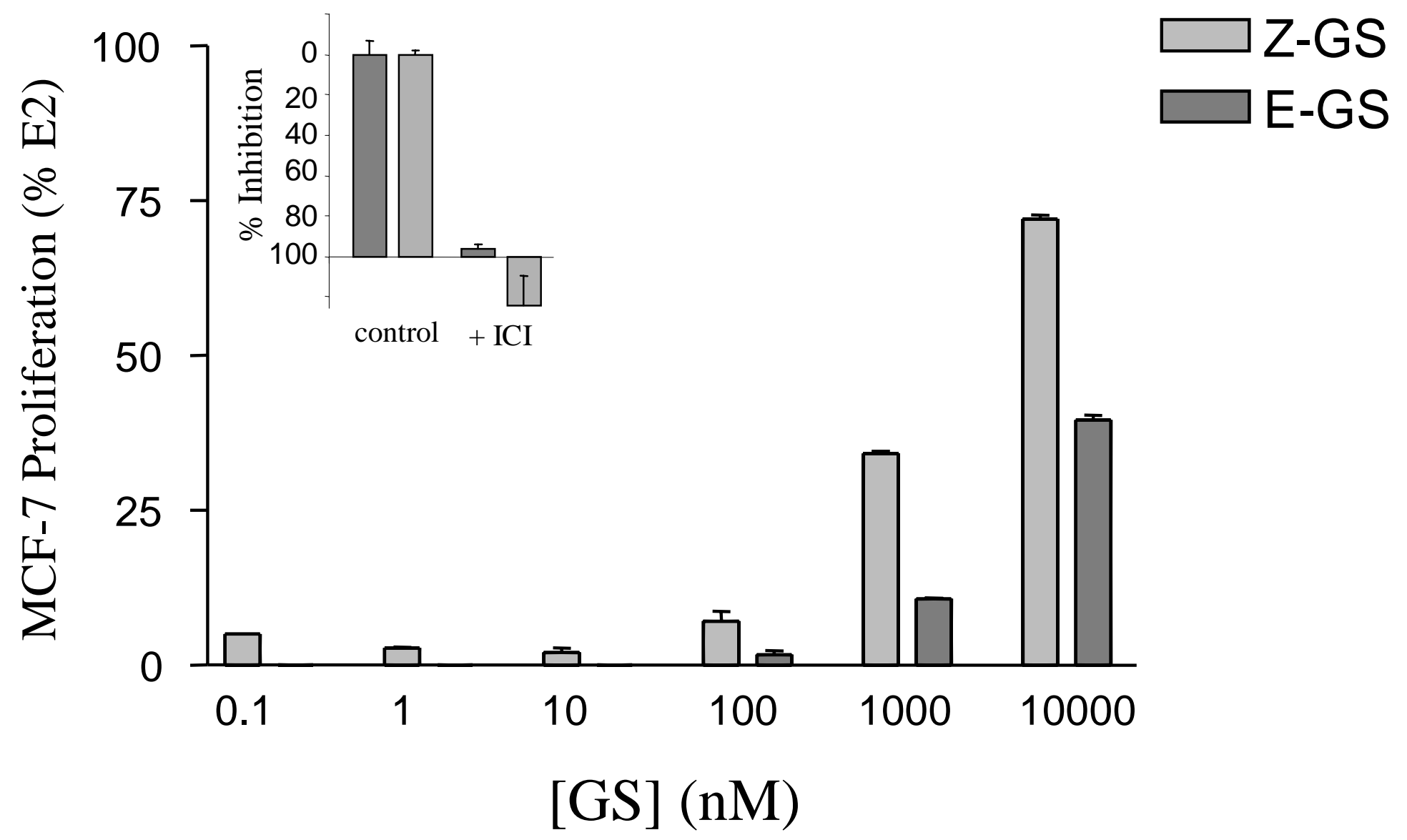


Figure 5A

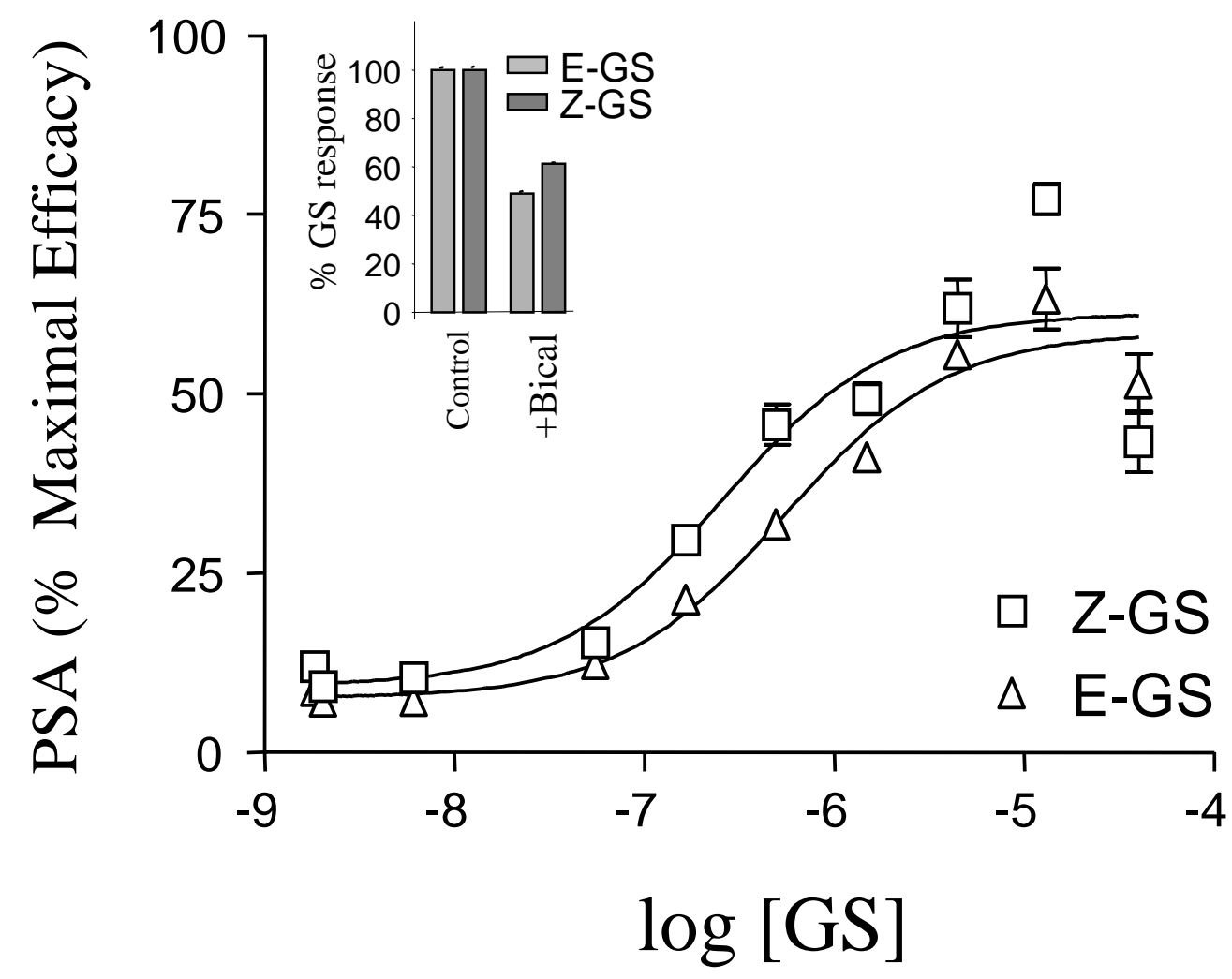


Figure 5B

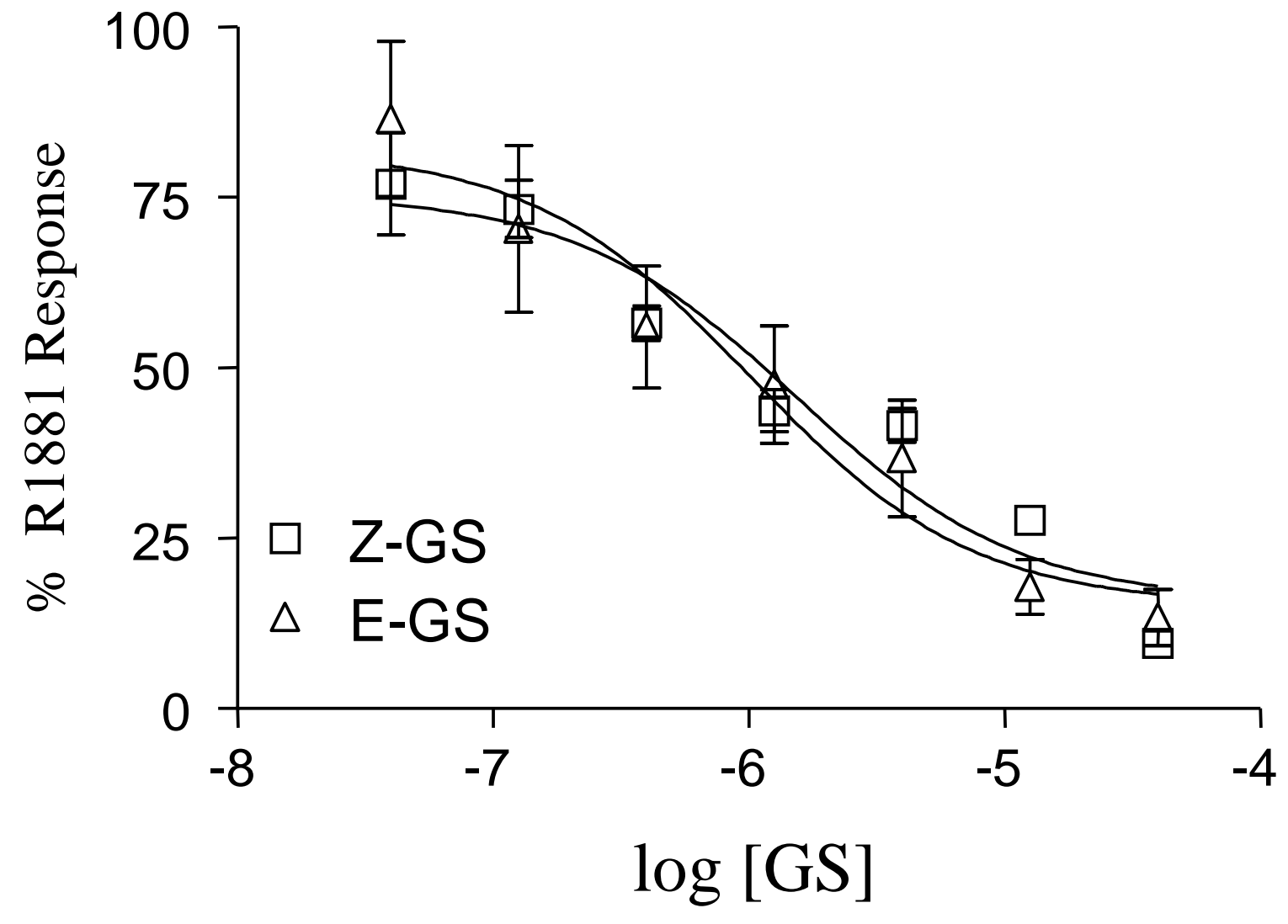


Figure 5C

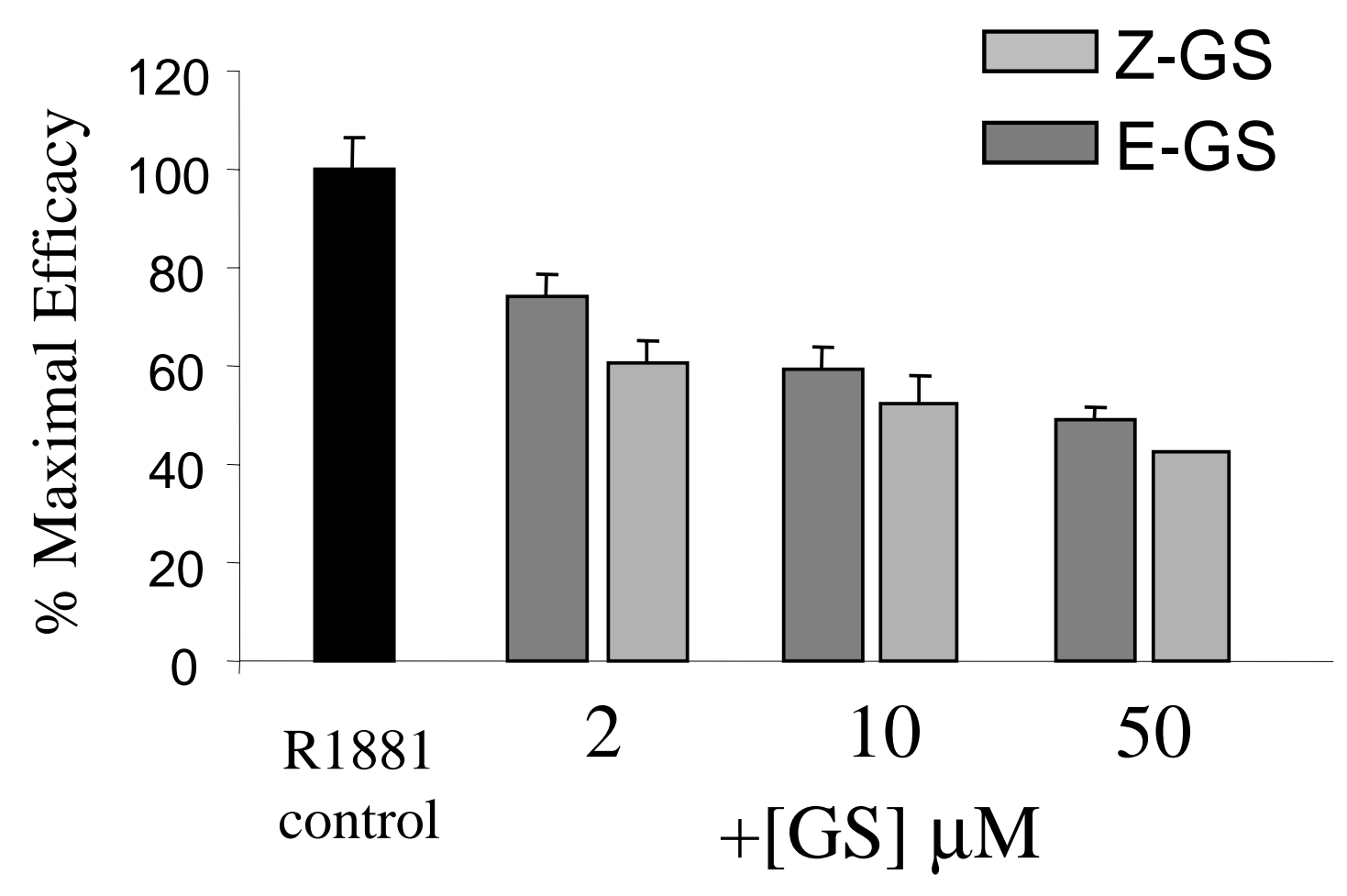


Figure 6

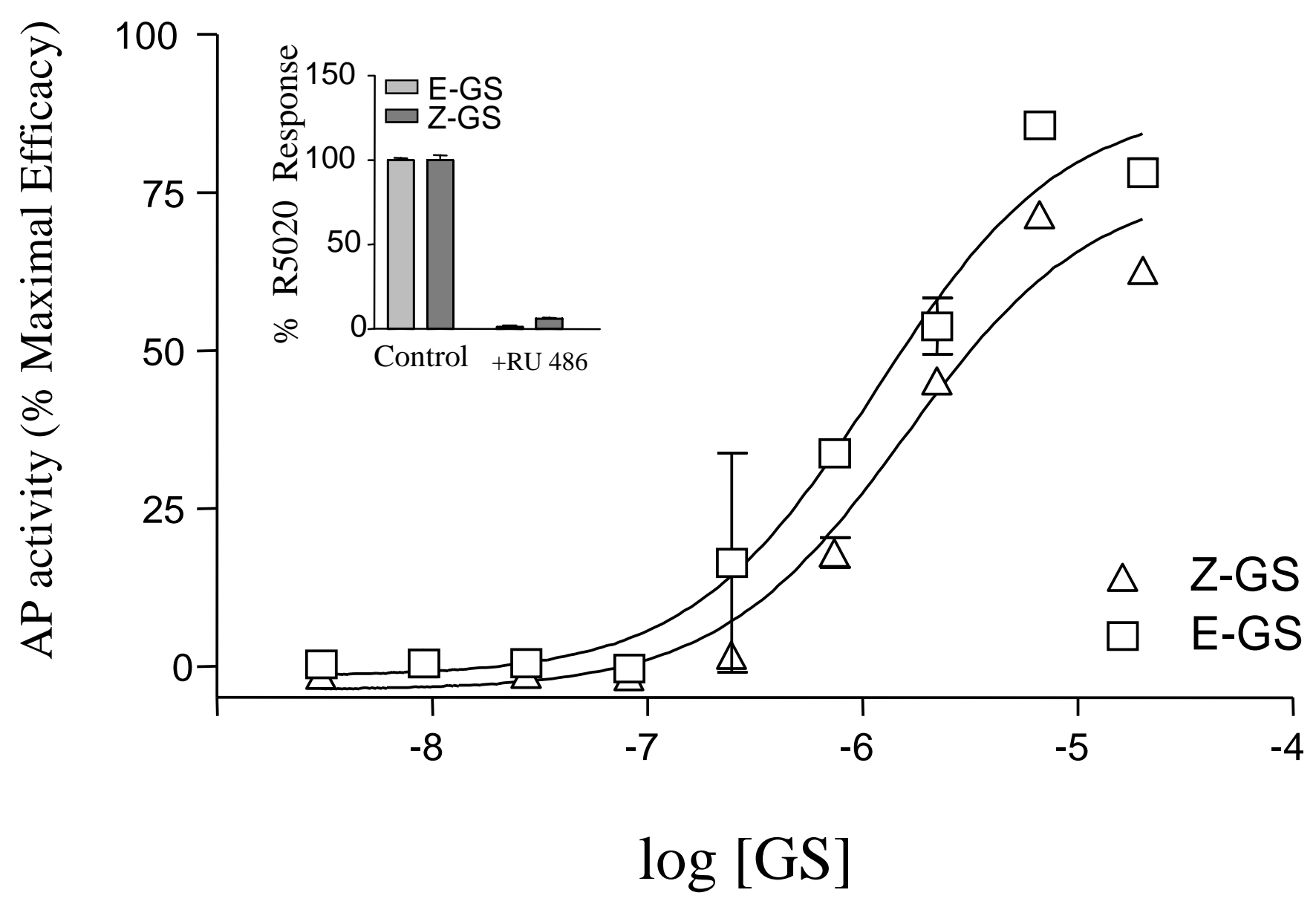

